OPEN ACCESS

Edited by:

Angel Borja

Centro Tecnológico Experto en

Innovación Marina y Alimentaria (AZTI), Spain

Reviewed by:

Serena Lucrezi,

North-West University, South Africa

Owen Molloy,

National University of Ireland

Galway, Ireland

*Correspondence:

Susanne Stoll-Kleemann

Susanne.Stoll-Kleemann@ uni-greifswald.de

Specialty section:

This article was submitted to Global Change and the Future Ocean,

a section of the journal

Frontiers in Marine Science

Received: 13 March 2019

Accepted: 07 May 2019

Published: 28 May 2019

Citation:

Stoll-Kleemann S (2019) Feasible Options for Behavior Change Toward More Effective Ocean Literacy: A Systematic Review.

Front. Mar. Sci. 6:273. doi: 10.3389/fmars.2019.00273

\section{Feasible Options for Behavior Change Toward More Effective Ocean Literacy: A Systematic Review}

\author{
Susanne Stoll-Kleemann * \\ Sustainability Science and Applied Geography, Institute of Geography and Geology, University of Greifswald, Greifswald, \\ Germany
}

Effective ocean literacy requires appropriate individual behavior, but achieving this-based on behavior change-is extremely difficult. Social-psychological research shows that even generating knowledge and awareness toward protecting the environment-including the oceans-very rarely produces behavior change. The correlation between knowledge and behavior change is demonstrably surprisingly low. Based upon a systematic interdisciplinary literature review, this article evaluates the factors constituting behavior that are important for ocean literacy. Furthermore, it includes an analysis of options for individual behavior change. The literature review covers research and theories from behavioral sciences such as social, environmental, and emotional psychology, as well as from other social sciences. Specifically, research on pro-environmental behavior is evaluated and applied to the specific case of ocean-related behaviors and ocean literacy. As a result, the model of pro-environmental behavior by Kollmuss and Agyeman has successfully been transferred to increase the effectiveness of ocean literacy because it considers internal (e.g., emotions and values) and external factors (e.g., politico-economic and socio-cultural), which are crucial to achieve behavior change. Further results show that the theoretical analysis of different influence factors of ocean related behavior help to identify options to enhance ocean literacy, partially not yet broadly applied in this field, such as reputation-based incentives, social marketing, and successfully diffusing social change, which is illustrated within two examples of success stories. Nevertheless, improvements remain challenging due to barriers identified on the individual level (e.g., cognitive dissonance and moral disengagement) and adverse political and economic power relations in light of rapidly increasing environmental problems in our oceans.

Keywords: ocean literacy, individual responsibility, sustainable behavior, behavior change, social norms, cognitive dissonance, moral disengagement, model of pro-environmental behavior

\section{INTRODUCTION}

Ocean environments are under exceptional pressure by anthropogenic activities leading to climate change, marine pollution, and overexploitation of fish stocks, with their severe negative impacts for marine ecosystems and humans-particularly in densely populated coastal regions (Lubchenco et al., 2016). The generally worse state of the oceans, with no area unaffected by human influence and a large fraction (41\%) strongly affected by multiple drivers, requires urgent, comprehensive, 
and efficient actions to save the oceans and prevent even more mis- and overuse (Halpern et al., 2008; Gattuso et al., 2018). Also, all kinds of land-based activities, such as related to tourism and urban growth, cause habitat destruction and overexploitation. More specifically, pollutants from households and industry and nutrients from agriculture lead to problems such as contamination and eutrophication (Billé et al., 2013; WBGU, 2013; EEA, 2015). Further sea-based problems, in addition to fishing and aquaculture, are noise pollution through ship traffic, renewable energy production, as well as oil and natural gas exploration (ibid).

Anthropogenic climate change is constantly becoming the biggest threat and has already led to increasing sea temperatures, ocean acidification, and additional changes like rising sea levels, increasing ocean stratification, decreasing sea-ice extent, altered patterns of ocean circulation, and modified oxygen content at the surface (Halpern et al., 2007; Doney et al., 2011; Borja et al., 2013; Gattuso et al., 2018; McCauley et al., 2019).

These complex interrelationships show the necessity of becoming "ocean literate," of course in addition to political action such as implementing the marine related Sustainable Development Goal 14 "Conserve and sustainably use the oceans, seas and marine resources for sustainable development" (United Nations, 2015). Ocean literacy is not only defined as the "understanding of the ocean's influence on you and your influence on the ocean" (Cava et al., 2005, p. 5, see also Santoro et al., 2017 for a comprehensive practical guide on ocean literacy; Fauville et al., 2018), but also as "being able to make informed and responsible decisions regarding the ocean and its resources" (Cava et al., 2005, p. 5). This second part of the definition is of particular importance because options and incentives for individual behavior change toward less harming and more protecting the oceans, their ecosystems, and related populations are urgently needed. A similar useful concept is ocean citizenship because it recognizes that individual behavior can impact coastal and marine spaces and therefore "reflects an individual's relationship with place-either in a direct sense through personal interaction (in this case with the ocean), or indirectly through resource use and lifestyle choice (in this case in relation to ocean resources)" (Fletcher and Potts, 2007, p. 521). In recent years, the concept of ocean citizenship has been expanded to include environmental behavior and requires massive behavioral changes at the individual level, e.g., related to consumer choice to reduce environmental impacts (McKinley and Fletcher, 2010; Jefferson et al., 2015; Santoro et al., 2017). However, both conceptsand this is important for this article-emphasize the role of individuals.

Responsibilities of individuals cannot be ignored: McKinley and Fletcher (2010) point out that "the degradation of the marine environment can be partially attributed to the collective dayto-day impact of the behavioral and lifestyle choices made by individuals" (p. 379). Conversely, individuals have the potential to substantially contribute toward sustainable futures on land and in the seas through exercising consumer choice, as well as reducing demands on fisheries and their own carbon footprint
(Vincent, 2011; Jefferson et al., 2015). For example, individual lifestyle choices directly influence energy consumption, material consumptions, and consequent emissions, representing 45-55\% of total energy use. The most important activities in this context are living car free; flying less; eating fewer animal-based products, in particular meat and cheese; using low-carbon transport; heating less and with green energy only; voting for "green" policies; and promoting and campaigning for a low-carbon future (Whitmarsh and O'Neill, 2011; Wynes and Kimberly, 2017). When it comes to oceans, one has to add activities such as living as plastic free as possible, eating no or only sustainably caught fish, and campaigning and engaging for ocean conservation.

The main research question of this article is what the barriers, opportunities and incentives are to encourage more ocean friendly behavior, based on an interdisciplinary and multifactor approach. In line with this, the article explores and summarizes the factors that shape ocean-relevant individual behavior, bearing in mind that it is often the common denominator underlying a necessary wider social movement to ensure the sustainable use of the ocean as a natural resource. This is particularly the case in situations in which responsibly designed environmental marine policies, regulations, and management strategies are lacking or implemented too slowly.

\section{METHODS}

Factors that influence ocean-related behavior were investigated on the basis of an interdisciplinary systematic literature review with an emphasis on behavioral sciences such as personality, emotional, social, and environmental psychology, but also from consumer and marketing research, sociological, educational, political and-of course-marine sciences. There are many such studies, but a synthesis and systematic analysis of them is lacking. According to Magliocca et al. (2015) it makes sense to "distill the findings of many narrowly focused analyses (i.e., "cases") to produce knowledge that is more generally applicable than may be derived from a single case" (p. 213). It was started by collecting together a bank of research studies based on an already existing constantly updated database of the author who does research on the issue of behavior change since a while. In addition, a type of snowball method was applied by tracking new references, in particular on ocean and marine related behavior but also on new studies on pro-environmental behavior in general. According to Greenhalgh and Peacock (2005), "in systematic reviews of complex and heterogeneous evidence [...] [as is the case for this paper] formal protocol-driven search strategies may fail to identify important evidence" (p. 1065). Based on an initial assessment of the literature and the studies found via the snowball methodology, keywords (such as ocean literacy, ocean governance, ocean citizenship, pro-environmental behavior, and sustainable consumption) were formulated to an additional search for literature on the ISI Web of Science and other search engines. The search returned publications were sorted according to the thematic fit of their titles and abstracts. 


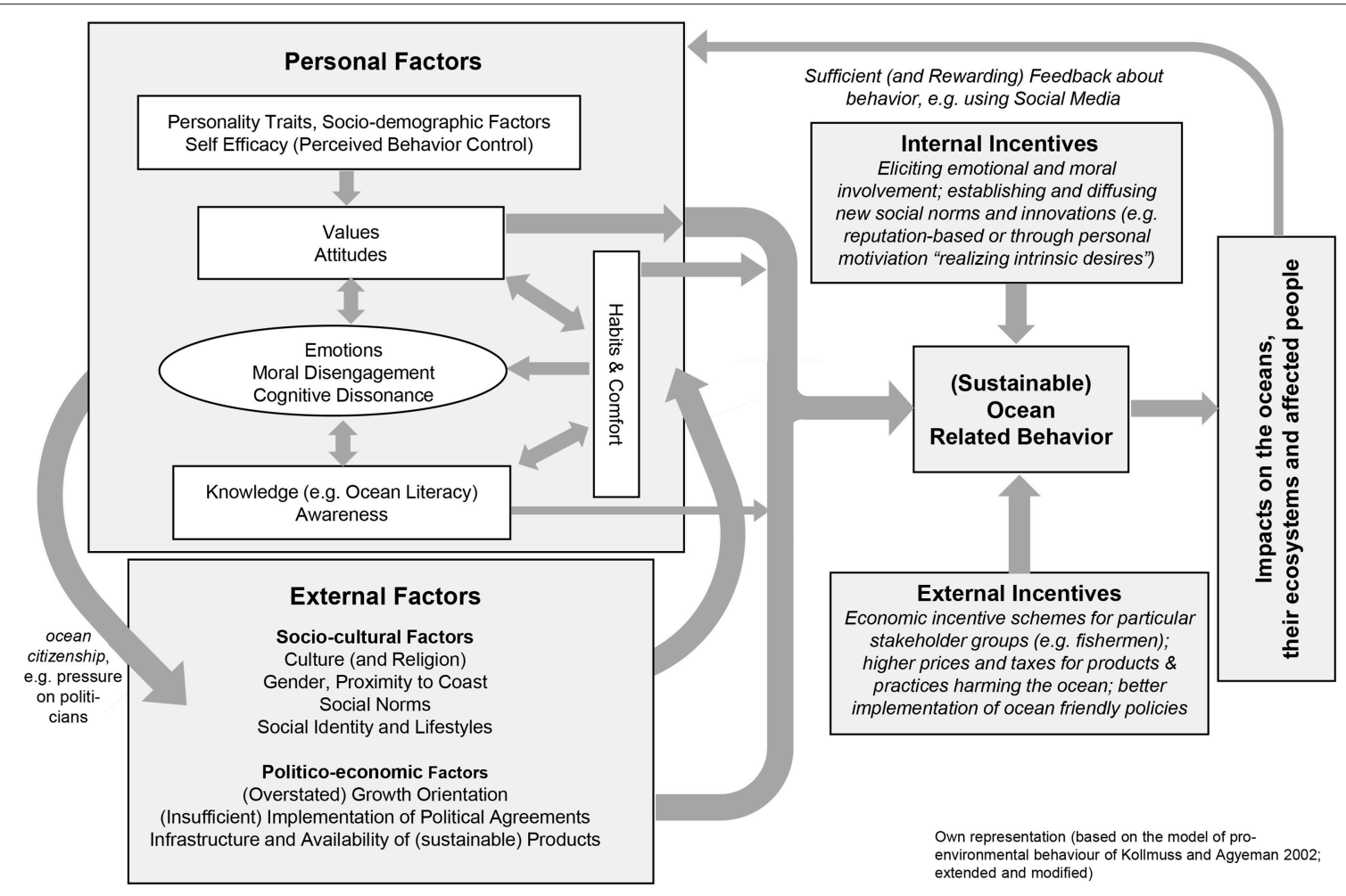

FIGURE 1 | Conceptual model of factors influencing ocean-related sustainable behavior.

The following criteria were met:

- The content had to relate to ocean related behavior in a wider sense (including environment and climate related) or at least to sustainable consumption behavior

- The results of the studies had to provide more or less generalizable evidence about factors

- Articles in peer-reviewed academic journals in English language in the time period of 2000-2019

In total, 102 papers were selected for the systematic literature review (see Electronic Supplementary Material).

The next step of the analysis was to code the selected studies. Code families included method (review, qualitative, quantitative), data background (empirical primary data, empirical secondary data, theoretical), thematic category (oceanrelated and sustainable consumption and pro-environmental (including climate related) behavior, and the context of factors that influence ocean related behavior (see below) with further sub-codes. The latter codes were generated from the model described below and previous peer-reviewed research (StollKleemann and Schmidt, 2017) and adapted to the particular issue of ocean related pro-environmental behavior (see Figure 1).

After analysis and structuring of the relevant research results from these articles the model of pro-environmental behavior developed by Kollmuss and Agyeman (2002) has been adopted and further factors have been incorporated. This decision has been supported by a review of a large number of theoretical frameworks on individual behavior based on Darnton's (2008) comprehensive overview of behavior-change models. The rationale of selecting and using this model for explaining (sustainable) ocean-related behavior lies mainly in its extensive breadth and its multifactor approach. According to Gifford and Nilsson (2014), many studies have shown that well-known established social-psychological models such as the theory of planned behavior (Ajzen, 1991), the value-belief-norm model (Stern, 2000), and the norm-activation theory (Schwartz, 1977) should be "expanded to include other personal and social factors" (Gifford and Nilsson, 2014, p. 141). Therefore, the model developed here is divided into two levels, namely personal (internal) and external factors (such as factors related to social norms, culture and religion, infrastructure and availability of sustainable products and politico-economic factors).

The emphasis in this article is on the multiple personal influence factors such as a person's personality traits and demographic factors as well as self-efficacy (perceived behavioral control). Knowledge, values and attitudes as factors are highly dependent on the information-processing system guided by emotions and the desire for comfort and a certain lifestyle. These are included in the model as they are core factors of behavior. In particular, habits and comfort are justified on the basis of processes such as cognitive dissonance and moral disengagement. They are at the center of the model because they help to understand personal reluctance to follow ocean-friendly practices. The interrelations among these groups of factors are 
also explicitly incorporated into the model, which increases its complexity, but also its explanatory power. This article has its focus on individual behavior; politico-economic factors are addressed, but in less detail compared to the discussion of personal factors. The arrows in the model indicate how the different factors influence each other and, ultimately, the probability of ocean-friendly behavior. On the right side of the box, a distinction is made between different incentives, more internal (e.g., establishing and diffusing more ocean-friendly social norms) on the one hand, and external, e.g., economic incentives on the other. These incentive structures should be supported by sufficient (or, if appropriate, even rewarding) feedback in regard to those behaviors leading to less harm for or protection of the oceans.

\section{RESULTS}

\section{Quantitative Assessment Quantitative Assessment of Studies of the Systematic Review}

The majority of the 102 articles reviewed $(n=52)$ employs a quantitative research approach, reflecting the representativeness of many results. Review articles $(n=39)$ indicate the general applicability of theories and evidence. Due to the importance of both personal and external factors in influencing (ocean-related) pro-environmental behavior, qualitative studies $(n=11)$ help to clarify complex behavior patterns (Figure 2A). The majority $(n$ $=90$ ) of the studies presents empirical data, of which the vast majority is primary data $(n=55)$. Twelve articles are theoretical essays and were included both to reflect current discussions and to explain theoretical models (Figure 2B). Some 24 of the 102 of the works cover aspects of purely ocean-related behavior. The remaining 78 focus on other sustainable consumption behaviors, mainly pro-environmental and/or climate related more generally (Figure 2C). Figure 2D shows the mean number of factors addressed per study (5.46 for ocean-related behavior and 6.09 for general pro-environmental behavior). This indicates that behavior is indeed multi-dimensional. Ocean-related behavior studies address nearly the same number of factors as more general ones, showing the relevance of synthesis.

In Figure 2E, it is evident that multiple factors are seen as important, but that there are several differences between ocean-related studies and the more general works on proenvironmental behavior. "Values \& Attitudes" is the most-oftennamed factor (79 studies overall) and nearly equally important in both types of studies. The second most-cited factor is related to "Economic/Political Aspects" $(n=63)$ and shows big differences between study types: in ocean-related works, this factor is described in $83.3 \%(n=20)$ of all articles, but only in $55.1 \%$ ( $n=043$ ) in the more general studies on pro-environmental behavior. A similar picture arises for the third-most-often named factor, "Social Norms" ( $n=61): 66.7 \%(n=52)$ of the general studies regard this factor as influencing behavior, but only $37.5, \%$ (n9) of the ocean-related studies describe this factor as relevant. The difference is even bigger for the factor "knowledge" $(n=58)$, with only $48.8 \%(n=38)$ of the general studies mentioning it as a factor; in contrast $83.3 \%(n=20)$ in the ocean-related articles cite it. Even where knowledge is expressly highlighted in the more general pro-environmental behavior studies, it is often framed as overestimated (see below, qualitative assessment).

Similarly, strong differences appear for the less-frequentlynamed factors "Social Identity \& Lifestyles" $(n=45)$; "SelfEfficacy/Perceived Behavior Control" $(n=35)$; "Habits \& Comfort" ( $n=33)$; and "Culture \& Religion" $(n=31)$, with the first three mentioned much more often in the general studies: "Social Identity \& Lifestyles" 52.6 vs. 16.7\%; "SelfEfficacy/Perceived Behavior Control" 41 vs. 12.5\%; and "Habits \& Comfort" 41 vs. $4.2 \%)$. In contrast, "Culture \& Religion" is strongly emphasized as an important factor in ocean-related studies (50 vs. $24.4 \%$ ). These differences mirror the fact that the majority of the general studies stems from the behavioral sciences. Nontheless, they clearly indicate that it would be worthwhile for studies on ocean-related behavior to consider reflecting on incorporating these kinds of factors as well. The factor "Emotions \& Cognitive Dissonance" is examined in 51 $(39+12)$ of the reviewed studies and equally often $(50 \%)$ in both types. Similarly, the factor "Personality Traits / Sociodemographic..." $(n=42$, i.e., $32+10)$ is also named equally often in both types (41\%). The external factor relating to "Sustainable Infrastructure \& Products" is named in 44 studies.

Overall, this quantitative assessment might suggest the importance of a variety of factors, but it may also provide insight into those that researchers view as important to examine with regard to pro-environmental and/or ocean-related behavior. Most of the studies $(n=81)$ were published between 2010 and 2019, highlighting the emerging research field (see Electronic Supplementary Material).

\section{Qualitative Assessment: Factors That Influence Ocean Related Behavior Personal Factors}

Increasing knowledge and awareness concerning ocean environments are at the heart of ocean literacy and often assumed as preconditions (or even a guarantee) for achieving sustainable ocean-related behavior. Professionals dealing with ocean literacy want individuals-at least-to "demand an understanding of ocean processes and the inter-connectivity of the land and sea" and-at best-to understand more contested and complex notions related to "sustainability, equity and democracy" (Fletcher and Potts, 2007). Results from several articles show that, in general, people who live in coastal areas are more aware of relevant ocean issues, but that the baseline awareness of the oceans is very low (see e.g., Steel et al., 2005; Fletcher and Potts, 2007; Potts et al., 2016; Fauville et al., 2018). In an empirical study focusing on Ireland, McCauley et al. (2019) found out that there is a lack of knowledge of important actors such as policy makers, teachers, and lecturers and, moreover, a lack of understanding of the importance of the ocean in our cultural, social, and environmental heritage, which makes it more difficult to deal with the issue at hand.

Nevertheless, even though living close to the coast generally leads to better knowledge of the oceans, it does not necessarily lead to changed behavior. There is no evidence that more knowledge, education, and public awareness of the oceans directly leads to sustainable behavior. Fletcher 


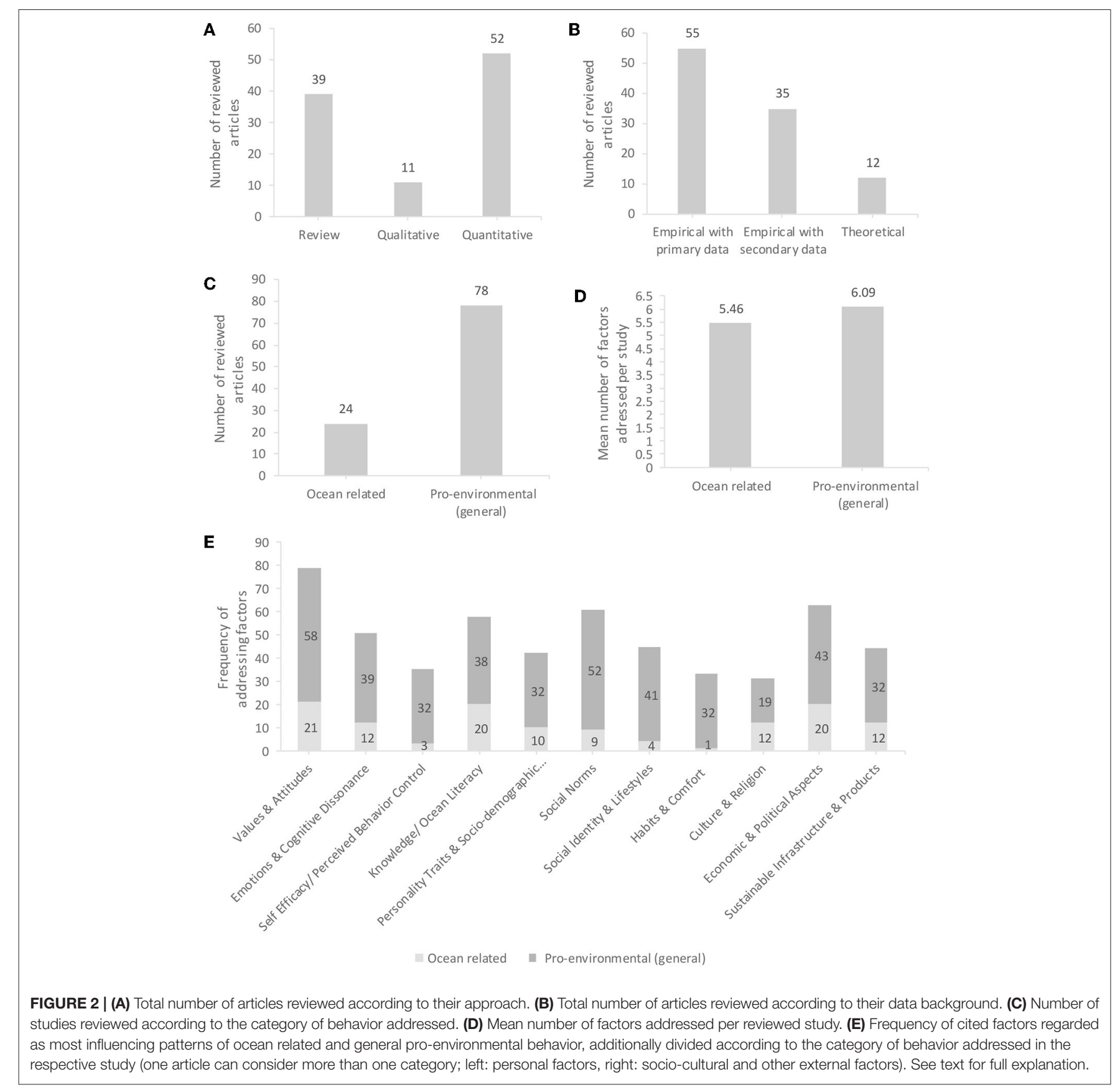

and Potts (2007) express the opinion that replacement of the common "surface learning" with "deep learning" would be helpful. "With deep learning, individuals understand the complexities and interconnections involved with the issue, including cause and effect. This implies that in order to exercise ocean citizenship, individuals must not only be aware of ocean issues, but understand how their behavior can affect, either positively or negatively, the oceans" (p. 513).

Unfortunately, although deep learning is certainly much more effective than surface learning in numerous respects, Fletcher's and Potts's opinion has not been confirmed by established research demonstrating that "only a small fraction of proenvironmental behavior can be directly linked to environmental knowledge and environmental awareness" (Kollmuss and Agyeman, 2002, p. 250). The gap between knowledge/awareness and behavior-which can be found in all areas of life-is explained by the fact that "at least $80 \%$ of the motives for pro-environmental or non-environmental behavior seem to be situational factors and other internal factors" (Barr et al., 2011; see also Barreto et al., 2014; ibid). In concrete terms, this means that although concern is expressed about ocean sustainability (see e.g., Gelcich et al., 2014; Potts et al., 2016), people ultimately give it a low priority in their lives within the context of everyday 
issues. Albert Bandura-one of the most influential psychologists and whose theory of selective moral disengagement is presented as an important explanation below-puts it like this: "Bountiful immediate rewards of consumptive lifestyles can easily override distant adverse effects, especially if slowly cumulative" (Bandura, 2007) - as it is the case with actions that harm our oceans.

In general, the mis- and overuse of the oceans pose significant challenges to our perceptual, cognitive, and affective information-processing system-similar to climate changemaking it and its threats difficult to engage with. The more abstract, dissimilar, and socially distant the impacts and ostensibly "real victims" seem to be-be they ecosystems including animals, members of faraway communities or, perhaps, future generations-the less morally obligated people will feel to act on their behalf (Markowitz and Shariff, 2012).

Another problem is the "blamelessness of unintentional action": no one wants to pollute the oceans or is purposefully trying to make it happen. Although the problems of our oceans are the direct result of intentional, goal-directed behavior, they are perceived by many individuals as unintentional, if unfortunate, side effects of such actions. These types of "unintentionally caused harms" are assessed less harshly than "equally severe but intentionally caused ones" (Markowitz and Shariff, 2012, p. 244).

What are the "other internal factors" mentioned above that determine our behavior if not knowledge and awareness? The principles underlying human behavior appear simple: namely, "to seek out and attain rewards and to avoid punishments or penalties" (Blaukopf and DiGirolamo, 2007, p. 626). However, it becomes clear that the process is more complex than the assumption of differentiating rewards: The internal factors include basic needs for survival and reproduction (primary rewards), but can be more abstract and cognitive in nature (secondary rewards). Positive cultural values that must be learned, such as thinking monetarily, acclaim, security, knowledge, and praise are also associated. Of course, rewards that produce feelings of pleasure and liking reinforce the behavior that achieves them (ibid, p. 627). The anticipation of rewards leads to motivated behavior that can also be labeled goal-directed behavior (ibid, p. 632). The three main motivations for behavior include (I) hedonic ones, which lead individuals to seek ways to improve how they feel; (II) those that sensitize individuals to gains or losses in changes in their financial or other resources; and (III) normative ones, which are concerned with the correctness of their behavior (Lindenberg and Steg, 2007; Howes and Gifford, 2009; Steg et al., 2014).

Values are important to consider for achieving effective ocean literacy because they are the "guiding principles" that individuals use to judge situations: a person's sense of right and wrong or what "ought" to be" (Darnton and Evans, 2013, p. 7). One value-related question is the degree to which individuals admit their personal responsibility for ocean sustainability, which should ideally embrace both individual and collective action. Because "behaviors of individual actors at the local scale influence interactions at the regional or global scale", and "the collective effect of individual behaviors influences the larger-scale properties such that actors adapt to the changing conditions of the system context" (Lubchenco et al., 2016, p. 14508; see also Ostrom, 2009), it becomes evident that the emphasis on the aggregative nature of the various types of ocean-related harm follows the principle that "even if an act harms no one, this act may be wrong because it is one of a set of acts that together harm other people" (Parfit, 1987 and Peeters et al., 2015, p. 76).

In general, values are more abstract concepts than norms and attitudes, which usually refer to specific actions, objects and situation. In addition, "people's values form an ordered systems of value priorities that characterize them as individuals" (Schwartz, 2006, 1). In the Schwartz Value Survey opposing values are benevolence ("preserving and enhancing the welfare of those with whom one is in frequent personal contact") with achievement ("personal success through demonstrating competence according to social standards") and universalism ("protection for the welfare of all people and for nature") with power ("social status and prestige, control or dominance over people and resources") (Schwartz, 2006, 11). Related to these general values Clayton (2018) found that political orientation is determining attitudes toward environmental policy with an overall dislike of environmental policies being characteristic of conservatives.

In line with this, values have also been considered in terms of orientations toward self and others (Messick and Mc Clintock, 1968). Individuals with cooperative (pro-social) orientations emphasize joint gains between self and other, whereas those with competitive and individualistic orientations (pro-self) emphasize gains to themselves (Lindenberg and Steg, 2007; Kaiser and Byrka, 2010; Howell, 2013; Steg et al., 2014; Reese and Jacob, 2015). Individuals who are more people oriented and less authoritarian (Schultz and Stone, 1994); have higher levels of moral development (Swearingen, 1990); and believe their actions will make a difference tend to be more environmentally concerned (Howell, 2013; Antonetti and Maklan, 2014).

Unfortunately, relations between values and environmental (also ocean-related) views may not be simple because people have multiple values-and these can conflict (see above and Stern, 2000; Lindenberg and Steg, 2007; Howes and Gifford, 2009; Howell, 2013). For example, the presence of other people at events where choices are made about behavior that affects the oceans can have a powerful effect on behavior. This component of social norms, which is related to perceptions of normative behavior by socially connected peers, can be a barrier as well as an opportunity because people adjust their behavior "to manage their public image and create a certain impression on others" (Higgs, 2015, p. 39, see also Griskevicius et al., 2010; Farrow et al., 2017). Social norms may be communicated directly via cultural practices in a given situation (Higgs, 2015; Farrow et al., 2017; more on cultural issues below).

In addition, personality traits-the best established are the "Big Five: openness to experience, conscientiousness, extraversion, agreeableness, and neuroticism" (McCrae and Costa, 1999)-influence environmental behavior. Kaiser and Byrka (2010) emphasize that with a more trait-like measurement "people's environmental engagement can be predicted with up to $80-90 \%$ ", in particular reflecting pro-social dispositions in relation to pro-environmental behavior (p. 72). In two 
different studies, greater environmental concern was related to greater openness and agreeableness (the tendency to be compassionate and cooperative rather than suspicious and antagonistic toward others) (Hirsh, 2010; Klein et al., 2019). In a wide-ranging set of studies, openness, agreeableness, and conscientiousness were strongly linked to environmental engagement across both individuals and nations (Milfont and Sibley, 2012). Conscientiousness is an important personality trait because a lack of it leads to impulsive behavior and a loss of self-control in the face of tempting unsustainable situations. This issue is also highly emphasized in the literature on "mindfulness" (see e.g., O'Brien, 2008; Amel et al., 2009; Ericson et al., 2014).

Related to consciousness is another important determinant of behavior, namely, habits. Habits are highly unconscious and embedded in routines and social practices (Heimlich and Ardoin, 2008; Southerton, 2013; Verplanken and Roy, 2016). They are difficult to change, as they are rewarding because they save time and energy (via the routines) and are a barrier to all kind of sustainable behaviors (Lewin, 1951; Stern, 2000; O'Riordan and Stoll-Kleemann, 2015). For example, many of our day-today food habits are routine, in that we eat often and without much deliberation, e.g., unsustainably caught fish. The trend toward "convenience" has been a major influence on foodpurchasing habits, frequently accompanied by the excessive involvement of plastics, and encouraged by a lack of time, skills, or interest in cooking. This demonstrates how behaviors are facilitated by the structures of the production and supply systems. The so-called "Consumption-Happiness Myth," which is based on neuropsychological research, explains how we are locked in consumption patterns based on mechanisms like habit formation, which interact to influence "our sense of self at the very deepest levels of consciousness" (Brannigan, 2011, p. 85). Consumption is also viewed as a social marker to construct social identities and lifestyles. Overall, "habitual and routine forms of action are more than a matter of individual deficiencies" (Southerton, 2013, p. 16). They are also "socially conditioned and shaped by culturally derived dispositions" (ibid, p.17).

More "positive" factors toward effective ocean literacy are self-efficacy and emotional involvement. In the behavioral models reviewed, it emerged that self-efficacy is an important determinant for pro-environmental behavior (Gifford and Nilsson, 2014; summarized by Antonetti and Maklan, 2014). According to Ajzen (1991), self-efficacy is defined as the "perceived ease or difficulty of performing the behavior" (p. 188). People who feel they have the self-efficacy to carry out a certain behavior are more likely to do so than those who perceive themselves as lacking the ability to behave in the desired way. The notion of self-efficacy may also be a matter of consumer sovereignty and environmental responsibility (Peattie, 2010; Ericson et al., 2014; Fischer and Barth, 2014; Girod et al., 2014).

Emotional involvement, understood as the ability to experience an emotional reaction when experiencing the ocean positively (e.g., because of a person's connection with the sea) and negatively when confronted with the multi-facet impacts of human-made ocean degradation such as fear, empathy, or a bad conscience ("cognitive dissonance" see below), is of high importance for effective ocean literacy with the final aim of behavioral change (Jefferson et al., 2015). Kollmuss and Agyeman (2002) conclude, "the stronger a person's emotional reaction, the more likely that person will engage in a new behavior" (p. 254, see also e.g., Han et al., 2016 introducing the "value-belief-emotionnorm model"). Jefferson et al. (2015) add that "by understanding emotions, engagement can be more than a knowledge-transfer exercise and can inform approaches by talking to the heart, not to the mind"; (...) by taking "opportunities for connection and greater involvement through building on uniqueness of an area, feelings of pride and identity"; and by "reviving cultural and historical feelings toward the marine environment" (p. 64).

This establishes a link to what Fletcher and Potts (2007) have described as "deep learning" (see above), which can ultimately lead to positive feelings such as "enlightenment and renewal" on the basis of the understanding of how individual behavior affects the oceans, either positively or negatively. "Renewal suggests that changed behavior can renew the environment through exerting less pressure upon it. Potentially of equal importance is personal renewal through the enhanced sense of well-being the changed behavior can induce-through doing the right thing" (p. 515).

Unfortunately, the analysis of several studies on environmental and sustainable behavior shows that a mechanism called cognitive dissonance acts as a barrier to feeling emotionally involved or processing new information adequately-and thus to behavioral change (Stoll-Kleemann et al., 2001; Stoll-Kleemann and Schmidt, 2017). Cognitive dissonance is a theory developed by Festinger (1957) in order to understand human behavior and, more specifically, human emotions. Following Kollmuss and Agyeman (2002), cognitive dissonance is also included in the conceptual model (see above) developed here. The literature reviewed confirms that people experience dissonance when they are reminded that their behavior may not match their values and attitudes, and the resolution of this tension by changing behavior (less fish/more sustainable fish/less or no plastic use/different consumption behavior, e.g., low-carbon oriented, etc.) is too painful or difficult (e.g., Stern, 2000; Thørgersen, 2004). However, people tend to avoid or resist information about the negative consequences of their unsustainable behavior because they contradict or threaten their basic perspectives on fairness and ethical behavior and can give rise to strong, emotionally distressing reactions (Stoll-Kleemann et al., 2001 and in detail, see below). Psychological responses aimed at relieving people of these negative feelings include denial and delegation as means of removing feelings of guilt (e.g., Kollmuss and Agyeman, 2002; Bamberg and Möser, 2007; Antonetti and Maklan, 2014; Reese and Jacob, 2015; Han et al., 2016). Because people who delegate or deny are unlikely to change their behavior toward sustainability, it is important to look at these mechanisms to find solutions to overcoming them.

The concept of selective moral disengagement explains in greater detail how the process of cognitive re-construing or re-framing of "destructive" behavior as being morally acceptable without changing the behavior or the moral standards works (Bandura, 1999). At its core is the mechanism of convincing the self that ethical standards do not apply to 
oneself in a particular context by means of disabling the mechanism of self-condemnation (Bandura, 1999; Moore, 2015). Different psychosocial mechanisms support the undermining and neutralizing of moral control and operate at both, the individual and social-systems level: among them is diffusing of responsibility for detrimental behavior. Collective action, which makes one's contribution seem trivial, is a popular form of selfexoneration for aggregate harmful effects. People may see little harm in conducting ocean related but unsustainable behavior since the individual impact seems small since the resource is so huge in size. Now, however, the cumulative effects of these actions have resulted in harming the oceans (a classical "tragedyof-the-commons situation" in which behavior "that makes sense from the individual point of view, when repeated by enough individuals, ultimately proves disastrous to society", Gardner and Stern, 1996, p. 23).

Displacement of responsibility is also problematic. Moral control operates most strongly when people acknowledge that they are contributors to harmful outcomes but this mechanism spares them self-disapproving reactions by shifting the responsibility to others or to situational circumstances. Social, economic and moral justifications sanctify harmful practices by investing them with worthy purposes. This enables people to preserve a sense of self-worth while causing harm by their activities, (Bandura, 2016). This practice is also omnipresent in political and everyday conversations encompassing beliefs such as the contention that significant consumption is necessary for maintaining jobs, or that eating (unsustainably caught) fish is necessary for a healthy diet.

Finally, it is important to mention the disregard, distortion or denial of harmful effects. Causality is difficult to gauge when the outcomes of behavioral practices are slowly cumulative and widely separated in time (Bandura, 2016). When people pursue activities that serve their interests but produce detrimental effects, they frequently attempt to avoid facing the harm they cause, or at least minimize it. If minimization does not work, the next strategy may be to discredit the scientific evidence of harm most prominently done for climate change (Bandura, 2007). Edvardsson Björnberg et al. (2017) point out that forms of organized denial can be easily detected: They encompass lobbying and propaganda performed by political, industrial and religious organizations and think-tanks. The "rationale for driving this grand denial project has been attributed to conservative ideology, vested interest in fossil fuels or a combination of these. Due to a misconceived application of the balancing principle in the media, denialist disinformation has been treated on par with scientific information" (p. 237).

\section{External Factors}

\section{Socio-cultural factors}

As pre-eminent socio-cultural factors, culture, religion, and the construction of social identities are influences that shape people's perceptions and behavior toward the ocean. According to Jefferson et al. (2015), it is essential to recognize the heterogeneity in society's connection with the sea-with influencing variables including age, gender, social values, or proximity to the coast (p. 62). By understanding public perceptions of the sea, particularly the ways in which people value and connect with the marine environment and the issues which affect it, it is, for example, easier to tailor marine-engagement campaigns. Santoro et al. (2017) add that ocean literacy has different meanings in different countries and culture and already in Europe with its many different basins and regional seas one has to consider different cultural contexts.

In the context of socio-cultural factors, it could happen that a group could have similar knowledge of a marine conservation issue but respond to different engagement approaches differently (Steel et al., 2005; Ostrom, 2009; Jefferson et al., 2015; Potts et al., 2016). Considering multiple variables of human behavior is inevitable, and in addition to the above-mentioned personal factors, this also applies to different cultural connections between society and the sea (for a list of factors see Ostrom, 2009). Jefferson et al. (2015) emphasize that the "cultural context is critical to understand how people engage with the sea. This was considered to enable a deeper appreciation of how the sea influences or is part of an audience's identity or sense of place" (p. 64). They illustrate the potential role of cultural/religious connections with an example from Bien Unido Reef Marine Park in the Philippines, which was threatened by blast- and cyanidefishing. Placing religious statues underwater resulted in dramatic declines of illegal activities, thereby supporting the Park's marineconservation objectives through the alignment of such priorities with cultural values (Jefferson et al., 2015).

Another interesting aspect related to culture-but also to the politico-economic sphere because power and agency play a role here-is the importance of gender. Gissi et al. (2018) suggest that "removing the cultural barriers of a male-dominated world for women to access governance of the oceans" will lead to achieving sustainability because "the marine environment and those dependent on it have much to gain from "blurring" lines or boundaries with regard to who has a mandate to govern ocean space and who has a say about the allocation of its resources" (p. 218). The authors built on an analysis of women's contributions in the maritime sectors, such as fisheries and marine conservation. It emerged that, e.g., "in conservation, women have frequently advocated for the common good, raising their voice for the common good. From studies on sustainability, it is clear that they are regarded as major actors of sustainable development due to their inclusiveness and collaborative roles" (p. 218).

\section{Politico-Economic Factors}

Sustainable ocean-related behavior would ideally require supportive government policies and practices, new and different business practices, and civil-society initiatives working in synergy. Many political agreements exist on various regional and sectoral levels to protect the environment, including the oceans and the climate, such as SDG 14, the UN Convention on the Law of the Seas (UNCLOS, 1982) on the international level, or the Water Framework Directive (European Commission, 2000) and the Directive for Maritime Spatial Planning and Integrated Coastal Management (European Commission., 2013), all on the European Union level, among others. In many cases, major implementation problems are based on a lack of political will 
such as observed by McCauley et al. (2019) for Ireland, where the government is slow to act on and implement marine-related issues and marine education.

Certainly the most depressing example when it comes to political failure concerning the implementation of important environmental and ocean-related agreements is the case of anthropogenic climate change (as one major threat to the oceans). For the Paris Agreement, which aims to limit global temperatures "well below" $2^{\circ} \mathrm{C}$ above pre-industrial levels, with the ultimate objective of reducing this to $1.5^{\circ} \mathrm{C}$ (UNFCCC, 2015), the probability of collective failure to achieve these goals is very high (Bandura, 2016; Bode, 2018). For example, to attain the $1.5^{\circ} \mathrm{C}$ pathway would involve immediate massive cuts in coal production and burning. Germany, the world's fourth-largest economy, is a concrete example of climate-policy failure: Its absolute coal use has increased in recent years by $11 \%$ (20092014), and it continues to provide significant subsidies to coaland has even recently introduced new subsidies for coal-fired power (Climate Transparency, 2017; Whitley et al., 2017; Bode, 2018). The country will not stop burning coal until the year 2038. In addition, the GHG emissions of Germany's transport sector are also growing. This failure is caused by "lock-in" effects from existing and currently constructed energy and transport infrastructure (Klein, 2014; Bode, 2018).

In general, our current market-driven capitalistic system, with its fatal dependence on growth conceived to increase consumption in all areas of life, leading to wasteful consumerism, is a major cause of exceeding planetary boundaries, including ocean destruction. Overconsumption with its "overzealous acquisitive desire stems from a feeling of emptiness or meaninglessness in one's life and that material consumption is a form of self-medication to soothe these bad feelings" (Amel et al., 2009 , p. 17). Related is the problem of aggressive advertisement that seeks to create new needs for "unnecessary" products; another is planned obsolescence (products with an artificially limited life span), which generates long-term sales by reducing the time between repeat purchases (O'Brien, 2008; Danciu, 2014; Ericson et al., 2014) and unsustainable options are still the default (Amel et al., 2009). Finally, widespread and, to a degree, very creatively masqueraded lobbying efforts based on strong interlacement with politics enjoy continuous significant success in shaping laws and weakening regulations in ways that work against any environmental-protection measures in a wider sense (Stern, 2000; Bandura, 2007; Billé et al., 2013; Danciu, 2014; Klein, 2014; O'Riordan and Stoll-Kleemann, 2015).

Some hope comes from Lubchenco et al. (2016), who report a few positive cases (generally being based on theoretical thoughts introduced by Eleanor Ostrom). On the local level, well-designed secure-access fisheries, also termed "rights-based fishery" (RBF), can convince individual fishers to undertake their work more sustainably. In 2016, there were already over 200 RBFs covering over 500 species in 40 countries (Lubchenco et al., 2016). The main mechanism consists of providing fishers with predictable access to a portion of the allocated harvest (either a share of the total allowable catch or an area in which to fish) with sciencebased catch limits, strong community engagement, and strong consideration of local conditions as essential success factors (ibid.). A completely different pathway-even on the national level-is to use debt-for-nature swaps as a way to reduce foreign debt in exchange for protection that includes oceans and their conservation (and not only for terrestrial systems as is generally common). "In 2015, the Republic of Seychelles exchanged US $\$ 27$ million worth of debt, for example, for increasing marine protection of its exclusive economic zone (EEZ) from $<1$ to $30 \%\left(400,000 \mathrm{~km}^{2}\right)$ through the creation of the second-largest marine-protected area in the West Indian Ocean. (...) The debtfor-nature swap allows the Seychelles to invest in its own local coastal economy-fisheries and tourism-rather than sending the money to other countries to cover debt" (Lubchenco et al., 2016, p. 14510).

But in general, it is evident that global, regional, and national approaches to resolve the problems are limited, while individual behavior is proposed as a "key policy channel" because individuals can place pressure on politicians through recognized democratic channels to address environmental concerns. For this to happen, it would be necessary to increase the capacity, as well as to create a stronger public "desire" to be involved, e.g., in the management of the marine environment, in order to achieve a higher degree and more credible implementation of environmental policies and international agreements. Of course, it must be admitted that this can be challenging because, particularly in the case of oceans, there are multiple nations bordering them, each with its own approach to ocean protection and cultural attitude toward individual responsibility, proenvironmental behavior, and lifestyle (Fletcher and Potts, 2007; McKinley and Fletcher, 2010, 2012).

\section{DISCUSSION}

\section{Feasible Options and Incentives Toward Ocean-Friendly Behavior}

Although it seems nearly impossible to change the overall current economic system, Lubchenco et al. (2016) show that an approach based on increasing reputation and toward a positive self-image can create conditions that also incentivize companies and countries, and not only individuals, to engage in activities that support sustainability. For example, marine reserves, which are "generally lobbied strongly against by powerful extractive industries (fishing, oil, gas, and mining)" and whose designation has been very difficult in the past, are now getting more support because of the announcement of a competition among global leaders to create the world's largest marine reserve. A second example-with the aim of improving fishery sustainability in the business sector-has been the pledge by large retailers to only source seafood products certified as sustainable. The result is that "more than $80 \%$ of North American retail and institutional food-service enterprises have seafood- sustainability policies, in partnership with environmental non-government organizations" (Lubchenco et al., 2016, p. 14512).

Although, ways to promote ocean-friendly behavior might include the provision of information about the consequences of unhealthy oceans and concrete ways of achieving a more intact marine environment, it makes no sense to simply address rational 
cognitive issues (Markowitz and Shariff, 2012; Bolderdijk et al., 2013; Darnton and Evans, 2013, p. 13; O'Riordan and StollKleemann, 2015; Han et al., 2016). It is better to include more emotional and "feeling" elements in choices regarding oceanrelevant behavior. Feelings regarding responsibility and guilt are particularly important because they are strongly connected to the willingness to make sacrifices for the environment (Bamberg and Möser, 2007; Jefferson et al., 2015; Han et al., 2016). In addition, in particular pride, hope, and gratitude as positive (moral) emotions play a key role in driving support for action (Markowitz and Shariff, 2012; Antonetti and Maklan, 2014).

In this context, Lubchenco et al. (2016) point out that altruism, ethical values, and reciprocity are powerful drivers of change because the intrinsic desire of individuals for a positive selfimage or to be seen by others in a certain positive way leads individual actors to do good to achieve personal satisfaction (see also Griskevicius et al., 2010). "This type of motivation can also apply when groups of actors work together to achieve a goal, creating a sense of camaraderie and shared investment that drives behavior. Even the perception of collective behavior can act as an incentive" (p. 14511; see also Barth et al., 2016).

In general, most people don't decide which behaviors to choose or which attitudes to hold based on a careful analysis (Cooney, 2011). Instead, people change their behavior through "the power of social modeling" and use the available information for their self-development (Bandura, 2016, p. 416). This is supported by Higgs (2015), who concludes that "humans have a highly developed capacity to learn from the behavior of others and to find the approval of others awarding and disapproval aversive." (p. 38). This is why approaches based on reputation and self-image of individual actors-reflecting larger social normswork so well (Bamberg and Möser, 2007; Barth et al., 2016; Lubchenco et al., 2016).

In fact, a small number of people-innovators-are willing to try out new ideas and behaviors. Of course, new ideas and behaviors that are more "fit" than older ones can radiate, as a growing number of people gradually adopt them. If conditions are right, these "fitter" ideas gradually replace older beliefs for a substantial portion of society (Christakis and Fowler, 2009; Cooney, 2011). In the case of sustainable consumption behavior, such as eating less fish or meat and using fewer plastics, it is necessary that the perception of "losing" something (such as materialistic goods or comfort) needs to be reversed and transferred into a perception of gaining a "good life" relieved from unnecessary ubiquitous consumption and "fulfillment through non-consumer experiences" such as a re-connect to the pleasures of social life and feeling nature (Amel et al., 2009). Focusing on these innovators and on early adopters can help build up the number of supporters for sustainable ocean-related behavior until it reaches the critical growth stage. At this point, the power of social networks kicks in, and the majority of the public begins to accept these ideas and behaviors due to having heard about them from friends and neighbors and having observed them in these people's own behavior (Christakis and Fowler, 2009; Barth et al., 2016).

One additional approach in support of this process can be facilitated by techniques used in community-based social marketing (Barr et al., 2011; Stoll-Kleemann and Schmidt, 2017). Findings from neuroscience also support the usefulness of socialmarketing strategies to influence our ocean-related behaviors, e.g., because they are able to limit the Consumption-Happiness Myth (Brannigan, 2011). Although social marketing "takes a page from the playbook of traditional advertising" to create behavior change (Cooney, 2011, p. 171), it is rather based on the idea that norms, commitment, and social diffusion have at their core the interactions of individuals in a community and aim at developing supportive social interaction (McKenzie-Mohr, 2000).

Similarly, Noppers et al. (2014) found that "the more people think that adopting a sustainable innovation has positive outcomes for their self-identity and social status, the more likely they are to adopt sustainable innovations" (p. 60). Because some people see ocean-friendly behaviors as this type of sustainable innovations, this seems to be a very promising approach. The authors recommend that "targeting symbolic attributes might need subtle and indirect methods as well" and employing lessons that "can possibly be drawn from promotion strategies of highstatus and innovative brands" (ibid., p. 61). One remarkable example is the conservation-marketing effort described below, which is successful in its specific pursuit of this line in promoting sustainable fish and cosmetics and influencing others to follow.

Although research on social networks demonstrates that whenever we get one person to make a change, it "will likely lead others to make a change, and we are more successful than we think," some people-namely, opinion leaders and "connectors"-are linked to and can reach out to many more people than others; they are therefore much more influential than the average person (Cooney, 2011, p. 152f;Christakis and Fowler, 2009). Connectors are people who have a large number of contacts across an array of social, cultural, professional, and economic circles and make a habit of introducing people who work or live in different circles to each other (Gladwell, 2000; Christakis and Fowler, 2009). Opinion leaders such as politicians, prominent business people or entertainers, and religious and civic leaders are also directly linked to a large number of people, but their biggest impact is in transmitting social norms through the culture, public-policy decisions and the social media (such as Twitter), with the latter ones getting more and more importance, also in the area of ocean literacy (see e.g., Wright et al., 2015; Kopke et al., 2019). Getting opinion leaders to support the idea of ocean-friendly behavior is a critical step in the diffusion process. The success story below shows how this can work in practice. In this case, role models' actions helped reduce an unsustainable behavior (flying) and launched a whole new movement on not flying in Sweden.

The "conventional" media (such as the TV) still play an important role because they "take in stories and attitudes from other people and transmit them as social norms to a huge audience" (Cooney, 2011, p. 166). For example, long-running serial dramas can serve as principal vehicles for promoting personal and social changes because "by dramatizing alternative behaviors and their effects on the characters' lives, the dramas help people make informed choices in their own lives. (...) Story lines that dramatize viewers' everyday lives and functional 
solutions get them deeply involved. Unlike brief exposures to media presentations that typically leave most viewers untouched, ongoing engagement in the evolving lives of models provides numerous opportunities to learn from them" (Bandura, 2016, p. 419f).

\section{Two Success Stories \\ "Air-Travel Shaming"}

The first example, not directly related to the oceans but to climate change, which-as mentioned-is highly influential in causing all kinds of ocean-related harms. In Sweden, a phenomenon called "air-travel shaming" has appeared in relation to flying, an individual behavior whose sum total causes a very high $\mathrm{CO}_{2}$ footprint and therefore harms other people, who are affected by the negative consequences of climate change. The process probably started with the successful biathlete Björn Ferry, a national celebrity who stopped flying some years ago. He now travels at least 13,000 km annually by train to competitions and his TV job as a commentator. No one in his family has flown for 2 years, and his wife and he are determined to live a completely fossil-free lifestyle by 2025. Another well-known Swedish opinion leader who understands the gravity of the issue is the country's Minister of Education and Cultural affairs, Alice Bah Kuhnke. In May 2018, she undertook official visits to Paris, Cannes, and Berlin by train. In fact, politicians across Sweden's entire political spectrum have committed themselves to giving up flying whenever possible.

The media have supported this trend, and the cultural editor of the nationwide newspaper Expressen recently decried the "idiotic lifestyle" of frequent flyers as the "most expensive suicide in world history." Researchers and artists have also registered their opinions, and a German newspaper commenting on the issue (Wolff, 2018) reports that for some, flying is no longer an alternative: jobs for which flying is obligatory are simply turned down.

Indeed, the Swedish railway system has witnessed a sharp increase in passenger numbers, whereas domestic and charterflight passenger figures are dropping. Other indicators of the movement's growing acceptance include a Facebook group dedicated to providing tips on long-distance train travel, whose membership has grown quickly to 30,000. And the Swedish expression "air-travel shaming" (flygskam) is quite likely to become the country's Word of the Year (Deutsche Welle, 2018). With this, Sweden truly serves as an example of the establishment of new social norms toward low-carbon behavior that can certainly apply to more ocean-related behaviors as well.

\section{“Project Ocean” (Summarized From Wright et al., 2015)}

The second example is a conservation-marketing experiment called "Project Ocean," which has been running since May 2011, consisting of a partnership between the luxury London department store Selfridges and the Zoological Society of London (ZSL). It is based on the concept of "retail activism" in which 22 non-profit organizations, in which celebrities, scientists, royalty, fishing industry representatives, youth group leaders, parliamentarians, heads of state, artists, fashion designers, and musicians have been brought together. Key messages of the campaign were aimed at "catching people's attention, such as giant panda "swimming" next to a southern bluefin tuna with the message "You wouldn't eat a panda" (Selfridges, 2019). This illustrated that this tuna species is more threatened than the giant panda. Activities to raise awareness extended throughout the store with consistent messages presented in a variety of ways, including art installations, interactive displays and a live exhibit, again guided by ZSL for technical content. These highlighted threats to marine ecosystems and conservation solutions the customer could engage with through informed purchasing choices and donating funds" (Wright et al., 2015, p. 45).

Selfridges changed their purchasing practices to select only sustainable seafood and provided tools to inform their customers how to do the same. The effort resulted in increased awareness among buyers as to the fish species they should eat. It also encompassed the recommendation that products containing shark oil should be eliminated from beauty products they purchased. Selfridges led by example and thus influenced the behavior of many of its suppliers, including their in-store franchises, as well as a sushi restaurant chain that switched to sustainable seafood both in its Selfridges branch and across their 80 UK restaurants as a result of Project Ocean. Selfridges has also addressed the issue of marine plastics through better retail "plastic practice" in a further campaign from 2015 on (Wright et al., 2015, p. 45).

\section{CONCLUSIONS}

In order to achieve effective ocean literacy, it is necessary to successfully activate sustainable ocean-friendly behavior. Providing knowledge on human-ocean interactions is only one piece in the jigsaw puzzle (Gifford, 2011; Bolderdijk et al., 2013) and some researchers even point out that "moral and educational approaches have generally disappointing track records, and even incentive- and community-based approaches rarely produce much change on their own" (Stern, 2000, p. 419). Instead, Stern (2000) continues "the most effective behavior change programs involve combinations of intervention types. These findings underline the limits of single-variable explanations for informing efforts at behavior change. The behavior is determined by multiple variables, sometimes in interaction" (p. 419).

Having this in mind, e.g., acknowledging women's roles in ocean issues for its effectiveness is an important contribution. Furthermore, moral disengagement needs to be overcome, since it is a key determinant of behavior harming the oceans, with its associated mechanisms such as diffusion and displacement of responsibility, moral economic and social justification, and disregard of harmful consequences. Moral disengagement may be lessened by the promotion of new social norms related to ocean-friendly behavior and their dissemination via social networks and other channels-as shown in the two success stories. If it were the "norm" to consume sustainable fish only, and not to fly or use plastics, or even to consume less and more sustainably in general, habits could be readjusted 
and become embedded in social practices and form a "new conformity." Realizing that small reductions are still very important in a collective behavior sphere, coupled with a strong sense of "starting together" and establishing a collective efficacy instead of waiting for others to act first, will remove the fear of individual sacrifices. In this way, feelings of a new social identity and more accommodative lifestyles may begin to appear.

To sum up, individuals can avoid damage to the oceans through modified lifestyle choice and behavioral change, leading to collectively improved ocean health. In return "for modified personal behavior, citizens will receive the benefits of healthy oceans, which may include enhanced resource options, aesthetic improvements to coastal areas, improved water quality, and ethical and moral benefits" (Fletcher and Potts, 2007, p. 513).

\section{REFERENCES}

Ajzen, I. (1991). The theory of planned behavior. Org. Behav. Hum. Decis. Proc. 50, 179-211. doi: 10.1016/0749-5978(91)90020-T

Amel, E. L., Manning, C. M., and Scott, B. A. (2009). Mindfulness and sustainable behavior: pondering attention and awareness as means for increasing green behavior. Ecopsychology 1, 14-24. doi: 10.1089/eco.2008.0005

Antonetti, P., and Maklan, S. (2014). Feelings that make a difference: how guilt and pride convince consumers of the effectiveness of sustainable consumption choices. J. Bus. Ethic. 124, 117-134. doi: 10.1007/s10551-013-1841-9

Bamberg, S., and Möser, G. (2007). Twenty years after hines, hungerford, and tomera: a new meta-analysis of psycho-social determinants of pro-environmental behavior. J. Environ. Psychol. 27, 14-25. doi: 10.1016/j.jenvp.2006.12.002

Bandura, A. (1999). Moral disengagement in the perpetration of inhumanities. Personal. Soc. Psychol. Rev. 3, 193-209. doi: 10.1207/s15327957pspr0303_3

Bandura, A. (2007). Impeding ecological sustainability through selective moral disengagement. Int. J. Innov. Sustain. Dev. 2, 8-35. doi: 10.1504/IJISD.2007.016056

Bandura, A. (2016). Moral Disengagement: How People Do Harm and Live With Themselves. NewYork, NY: Worth Publishers.

Barr, S. W., Gilg, A. W., and Shaw, G. (2011). Citizens, consumers and sustainability: (Re)framing environmental practice in an age of climate change. Glob. Environ. Change 21, 1224-1233. doi: 10.1016/j.gloenvcha.2011. 07.009

Barreto, M. L., Szóstek, A., Karapanos, E., Nunes, N. J., Pereira, L., and Quintal, F. (2014). Understanding families' motivations for sustainable behaviors. Comput. Hum Behav. 40, 6-15. doi: 10.1016/j.chb.2014.07.042

Barth, M., Jugert, P., and Fritsche, I. (2016). Still underdetected - social norms and collective efficacy predict the acceptance of electric vehicles in Germany. Trans. Res. Part F. 37, 64-77. doi: 10.1016/j.trf.2015.11.011

Billé, R., Kelly, R., Biastoch, A., Harrould-Kolieb, E., Herr, D., Joos, F., et al. (2013). Taking action against ocean acidification: a review of management and policy options. Environ. Manag. 52, 761-779. doi: 10.1007/s00267-0130132-7

Blaukopf, C. L., and DiGirolamo, G. J. (2007). Reward, context and human behavior. Sci. World J. 7, 626-640. doi: 10.1100/tsw.2007.122

Bode, T. (2018). Die Diktatur der Konzerne. Wie Globale Unternehmen uns Schaden und die Demokratie Zerstören. Frankfurt: S. Fischer Verlag.

Bolderdijk, J. W., Gorsira, M., Keizer, K., and Steg, L. (2013). Values determine the (in)effectiveness of informational interventions in promoting pro-environmental behavior. PLOS ONE 8:e83911. doi: 10.1371/journal.pone.0083911

Borja, A., Elliott, M., Andersen, J. H., Carstensensen, J., Cardoso, A., Ferreira, J., et al. (2013). Good environmental status of marine ecosystems: what is it and how do we know when we have attained it? Mar. Pollut. Bull. 76, 16-27. doi: 10.1016/j.marpolbul.2013.08.042

Brannigan, F. (2011). "Dismantling the consumption-happiness myth: a neuropsychological perspective on the mechanisms that lock us into

\section{AUTHOR CONTRIBUTIONS}

The author confirms being the sole contributor of this work and has approved it for publication.

\section{ACKNOWLEDGMENTS}

I would like to thank Gloria Denfeld for comprehensive editing support.

\section{SUPPLEMENTARY MATERIAL}

The Supplementary Material for this article can be found online at: https://www.frontiersin.org/articles/10.3389/fmars. 2019.00273/full\#supplementary-material

unsustainable consumption," in: Engaging the Public with Climate Change, eda L. Whitmarsh, S. O’Neill and I. Lorenzoni. (London: Earthscan), 84-99.

Cava, F., Schoedinger, S., Strang, C., and Tuddenham, P. (2005). Science Content and Standards for Ocean Literacy: a Report on Ocean Literacy. Available online at: http://coexploration.org/oceanliteracy/documents/OLit2004-05_Final_ Report.pdf (accessed March 01, 2019).

Christakis, N. A., and Fowler, J. H. (2009). Connected: The Surprising Power of Our Social Networks and How They Shape Our Lives. New York, NY: Little Brown \& Company.

Clayton, S. (2018). The role of perceived justice, political ideology, and individual and collective framing in support for environmental policies. Soc. Just. Res. 31, 219-237. doi: 10.1007/s11211-018-0303-z

Climate Transparency (2017). Brown to Green: The G20 Transition to a LowCarbon Economy. Berlin: Climate Transparency. Retrieved from: www.climatetransparency.org (accessed December 17, 2018).

Cooney, N. (2011). Change of Heart: What Psychology Can Teach us About Spreading Social Change. New York, NY: Lantern Books.

Danciu, V. (2014). Manipulative marketing: persuasion and manipulation of the consumer through advertising. Theoret. Appl. Econ. 591, 19-34.

Darnton, A. (2008). Reference Report: An Overview of Behaviour Change Models and Their Uses. Centre for Sustainable Development. University of Westminster.

Darnton, A., and Evans, D. (2013). Influencing Behaviours. A Technical Guide to the ISM Tool. Edinburgh: The Scottish Government.

Deutsche Welle (DW) (2018). Living Planet: A Flying Shame. Retrieved from: https://www.dw.com/en/living-planet-a-flying-shame/av-46406305 (accessed December 17, 2018).

Doney, S. C., Ruckelshaus, M., Duffy, J. E., Barry, J. P., Chan, F., English, C. A., et al. (2011). Climate change impacts on marine ecosystems. Ann. Rev. Mar. Sci. 4, 11-37. doi: 10.1146/annurev-marine-041911-111611

Edvardsson Björnberg, K., Karlsson, M., Gilek, M., and Hansson, S. O. (2017). Climate and environmental science denial: a review of the scientific literature published in 1990-2015. J. Clean. Product. 167, 229-241. doi: $10.1016 /$ j.jclepro.2017.08.066

EEA (2015). State of Europe's Seas. EEA Report 2. Copenhagen.

Ericson, T., Kjønstad, B. G., and Barstad, A. (2014). Mindfulness and sustainability. Ecol. Econ. 104, 73-79. doi: 10.1016/j.ecolecon.2014.04.007

European Commission (2000). Directive 2000/60/EC of the European Parliament and of the Council: Establishing a Framework for Community Action in the Field of Water Policy. (WFD, 2000/60/EC).

European Commission. (2013). Directive of the European Parliament and of the Council: Establishing a Framework for Maritime Spatial Planning and Integrated Coastal Management. Final report. (COD) 2013/0074.

Farrow, K., Grolleau, G., and Ibanez, L. (2017). Social norms and proenvironmental behavior: a review of the evidence. Ecol. Econ. 140, 1-13. doi: 10.1016/j.ecolecon.2017.04.017

Fauville, G., Strang, C., Cannady, M. A., and Chen, Y. F. (2018). Development of the international ocean literacy survey: measuring knowledge across the world. Environ. Edu. Res. 1-26. doi: 10.1080/13504622.2018.1440381. [Epub ahead of print]. 
Festinger, L. (1957). A Theory of Cognitive Dissonance. Stanford, CA: Stanford University Press.

Fischer, D., and Barth, M. (2014). Key competencies for and beyond sustainable consumption. An educational contribution to the debate. GAIA-Ecol. Perspect. Sci. Soc, 193-200. doi: 10.14512/gaia.23.S1.7

Fletcher, S., and Potts, J. (2007). Ocean citizenship: an emergent geographical concept. Coast. Manag. 35, 511-524. doi: 10.1080/08920750701525818

Gardner, G. T., and Stern, P. C. (1996). Environmental Problems and Human Behavior. Needham Heights, MA: Allyn and Bacon.

Gattuso, J. P., Magnan, A. K., Bopp, L., Cheung, W. W., Duarte, C. M., Hinkel, J., et al. (2018). Ocean solutions to address climate change and its effects on marine ecosystems. Front. Mar. Sci. 5:337. doi: 10.3389/fmars.2018.00337

Gelcich, S., Buckley, P., Pinnegar, J. K., Chilvers, J., Lorenzoni, I., Terry, G., et al. (2014). Public awareness, concerns, and priorities about anthropogenic impacts on marine environments. PNAS 111, 15042-15047. doi: $10.1073 /$ pnas. 1417344111

Gifford, R. (2011). The dragons of inaction: Psychological barriers that limit climate change mitigation and adaptation. Am Psychol. 66, 290-302. doi: $10.1037 / \mathrm{a} 0023566$

Gifford, R., and Nilsson, A. (2014). Personal and social factors that influence proenvironmental concern and behaviour: a review. Int. J. Psychol. 49, 141-157. doi: 10.1002/ijop.12034

Girod, B., van Vuuren, D. P., and Hertwich, E. G. (2014). Climate policy through changing consumption choices: options and obstacles for reducing greenhouse gas emissions. Glob. Environ. Change 25, 5-15. doi: 10.1016/j.gloenvcha.2014.01.004

Gissi, E., Portman, M. E., and Hornidge, A. K. (2018). Un-gendering the ocean: why women matter in ocean governance for sustainability. Mar. Policy 94, 215-219. doi: 10.1016/j.marpol.2018.05.020

Gladwell, M. (2000). The Tipping Point: How Little Things Can Make a Big Difference. New York, NY: Little Brown.

Greenhalgh, T., and Peacock, R. (2005). Effectiveness and efficiency of search methods in systematic reviews of complex evidence: audit of primary sources. BMJ 331, 1064-1065. doi: 10.1136/bmj.38636.593461.68

Griskevicius, V., Van den Bergh, B., and Tybur, J. M. (2010). Going green to be seen: status, reputation, and conspicuos conservation. J. Personal. Soc. Psychol. 98, 393-404. doi: 10.1037/a0017346

Halpern, B. S., Selkoe, K. A., Micheli, F., and Kappel, C. V. (2007). Evaluating and ranking the vulnerability of global marine ecosystems to anthropogenic threats. Conserv. Biol. 21, 1301-1315. doi: 10.1111/j.1523-1739.2007.00752.x

Halpern, B. S., Walbridge, S., Selkoe, K. A., Kappel, C. V., Micheli, F., D’Agrosa, C., et al. (2008). A global map of human impact on marine ecosystems. Science 319, 948-952. doi: 10.1126/science.1149345

Han, H., Hwang, J., and Lee, M. J. (2016). The value-belief-emotion-norm model: investigating customers' eco-friendly behavior. J. Travel Tour. Market. 34, 590-607. doi: 10.1080/10548408.2016.1208790

Heimlich, J. E., and Ardoin, N. M. (2008). Understanding behavior to understand behavior change: a literature review. Environ. Edu. Res. 14, 215-237. doi: $10.1080 / 13504620802148881$

Higgs, S. (2015). Social norms and their influence on eating behaviours. Appetite 86, 38-44. doi: 10.1016/j.appet.2014.10.021

Hirsh, J. B. (2010). Personality and environmental concern. J. Environ. Psychol. 30, 245-248. doi: 10.1016/j.jenvp.2010.01.004

Howell, R. A. (2013). It's not (just) “the environment, stupid!” Values, motivations, and routes to engagement of people adopting lower-carbon lifestyles. Glob. Environ. Change 23, 281-290. doi: 10.1016/j.gloenvcha.2012.10.015

Howes, Y., and Gifford, R. (2009). Stable or dynamic value importance? The interaction between value endorsement level and situational differences on decision-making in environmental issues. Environ. Behav. 41, 549-582. doi: $10.1177 / 0013916508318146$

Jefferson, R., McKinley, E., Capstick, S., Fletcher, S., Griffin, H., and Milanese, M. (2015). Understanding audiences: making public perceptions research matter to marine conservation. Ocn. Coast. Manag. 115, 61-70. doi: 10.1016/j.ocecoaman.2015.06.014

Kaiser, F. G., and Byrka, K. (2010). Environmentalism as a trait: gauging people's procial personality in terms of environmental engagement. Int. J. Psychol. 46, 71-79. doi: 10.1080/00207594.2010.516830
Klein, N. (2014). This Changes Everything: Capitalism vs. the Climate. New York, NY: Allen Lane.

Klein, S. A., Heck, D. W., Reese, G., and Hilbig, B. E. (2019). On the relationship between Openness to Experience, political orientation, and pro-environmental behavior. Personal. Indiv. Diff. 138, 344-348. doi: 10.1016/j.paid.2018.10.017

Kollmuss, A., and Agyeman, J. (2002). Mind the gap: why do people act environmentally and what are the barriers to proenvironmental behavior? Environ. Edu. Res. 8, 239-260. doi: 10.1080/13504620220145401

Kopke, K., Black, J., and Dozier, A. (2019). Stepping Out of the Ivory Tower for Ocean Literacy. Front. Mar. Sci. 6, 1-13. doi: 10.3389/fmars.2019.00060

Lewin, K. (1951). Field Theory in Social Science. New York, NY: Harper \& Row.

Lindenberg, S., and Steg, L. (2007). Normative, gain and hedonic goal frames guiding environmental behavior. J. Soc. Issues 63, 117-137. doi: 10.1111/j.1540-4560.2007.00499

Lubchenco, J., Cerny-Chipman, E. B., Reimer, J. N., and Levin, S. A. (2016). The right incentives enable ocean sustainability successes and provide hope for the future. Proc. Nat. Acad. Sci. 113, 14507-14514. doi: 10.1073/pnas.1604982113

Magliocca, N. R., Rudel, T. K., Verburg, P. H., McConnell, W. J., and Mertz, O., Gerstner, et al. (2015). Synthesis in land change science: methodological patterns, challenges, and guidelines. Reg. Environ. Change 15, 211-226. doi: 10.1007/s10113-014-0626-8

Markowitz, E. M., and Shariff, A. F. (2012). Climate change and moral judgement. Nat. Clim. Change 2, 243-247. doi: 10.1038/NCLIMATE1378

McCauley, V., McHugh, P., Davison, K., and Domegan, C. T. (2019). Collective intelligence for advancing ocean literacy. Environ. Edu. Res. 1-12. doi: 10.1080/13504622.2018.1553234. [Epub ahead of print].

McCrae, R. R., and Costa, P. T. (1999). "A five-factor theory of personality," in: Handbook of personality: Theory and Research, 2nd edn, eds L. A. Pervin and O. P. John (New York, NY: Guilford Press), 139-153.

McKenzie-Mohr, D. (2000). Promoting sustainable behavior: an introduction to community-based social marketing. J. Soc. Issues 56, 543-554. doi: 10.1111/0022-4537.00183

McKinley, E., and Fletcher, S. (2010). Individual responsibility for the oceans? An evaluation of marine citizenship by UK marine practitioners. Ocn. Coast. Manag. 53, 379-384. doi: 10.1016/j.ocecoaman.2010.04.012

McKinley, E., and Fletcher, S. (2012). Improving marine environmental health through marine citizenship: a call for debate. Mar. Pol. 36, 839-843. doi: 10.1016/j.marpol.2011.11.001

Messick, D. M., and Mc Clintock, C. (1968). Motivational bases of choices in experimental games. J. Exp. Soc. Psychol. 4, 1-25. doi: 10.1016/0022-1031(68)90046-2

Milfont, T. L., and Sibley, C. G. (2012). The big five personality traits and environmental engagement: associations at the individual and societal level. J. Environ. Psychol. 32, 187-195. doi: 10.1016/j.jenvp.2011.12.006

Moore, C. (2015). Moral disengagement. Curr. Opin. Psychol. 6, 199-204. doi: 10.1016/j.copsyc.2015.07.018

Noppers, E. H., Keizer, K., Bolderdijk, J. W., and Steg, L. (2014). The adoption of sustainable innovations: Driven by symbolic and environmental motives. Glob. Environ. Change 25, 52-62. doi: 10.1016/j.gloenvcha.2014.01.012

O'Brien, C. (2008). Sustainable happiness: how happiness studies can contribute to a more sustainable future. Can. Psychol. Psychol. Can. 49, 289. doi: $10.2139 /$ ssrn.2119614

O'Riordan, T., and Stoll-Kleemann, S. (2015). The challenges of changing dietary behavior toward more sustainable consumption. Environ. Sci. Pol. Sustain. Dev. 57, 4-13. doi: 10.1080/00139157.2015.1069093

Ostrom, E. (2009). A general framework for analyzing sustainability of socialecological systems. Science 325, 419-422. doi: 10.1126/science.1172133

Parfit, D. (1987). Reasons and Persons. (Edition with Corrections). Oxford: University Press.

Peattie, K. (2010). Green consumption: behavior and norms. Ann. Rev. Environ. Res. 35, 195-228. doi: 10.1146/annurev-environ-032609-094328

Peeters, W., De Smet, A.D., Diependaele, L., and Sterckx, S. (2015). Climate Change and Individual Responsibility: Agency, Moral Disengagement and the Motivational Gap. Basingstoke: Palgrave Macmillan.

Potts, T., Pitta, C., O'Higgins, T., and Mee, L. (2016). Who cares? European attitudes towards marine and coastal environments. Mar. Policy 72, 59-66. doi: 10.1016/j.marpol.2016.06.012 
Reese, G., and Jacob, L. (2015). Principles of environmental justice and pro-environmental action: A two-step process model of moral anger and responsibility to act. Environ. Science \& Policy 51, 88-94. doi: 10.1016/j.envsci.2015.03.011

Santoro, F., Scowcraft, G., Santin, S., Fauville, G., and Tuddenheim, P. (2017). Ocean Literacy for all - a Toolkit. IOC/UNESCO and UNESCO Venice Office, (Paris, IOC Manuals and Guides 80).

Schultz, P. W., and Stone, W. F. (1994). Authoritarianism and attitudes toward the environment. Environ. Behav. 26, 25-37.

Schwartz, S. H. (1977). Normative influences on altruism. Adv. Exp. Soc. Psychol. 10, 221-279. doi: 10.1016/S0065-2601(08)60358-5

Schwartz, S. H. (2006). Basic Human Values: An Overview. The Hebrew Uniersity of Jerusalem. Available online at: https://www.researchgate.net/publication/ 237364051_Basic_Human_Values_An_Overview (accessed March 12, 2019).

Selfridges (2019). Project Ocean. Available online at: http://www.selfridges.com/ $\mathrm{DE} / \mathrm{en} /$ features/articles/content/project-ocean?rd=projectocean (accessed March 1, 2019).

Southerton, D. (2013). Habits, routines and temporalities of consumption: From individual behaviors to the reproduction of everyday practices. Time Soc. 22, 335-355. doi: 10.1177/0961463X12464228

Steel, B.S., Smith, C., Opsommer, L., Curiel, S., and Warner-Steel, R. (2005). Public ocean literacy in the United States. Ocn. Coast. Manag. 48, 97-114. doi: 10.1016/j.ocecoaman.2005.01.002

Steg, L., Bolderdijk, J. W., Keizer, K. E., and Perlaviciute, G. (2014). An integrated framework for encouraging pro-environmental behavior: the role of values, situational factors and goals. J. Environ. Psychol. 38, 104-115. doi: 10.1016/j.jenvp.2014.0.002

Stern, P. C. (2000). Toward a coherent theory of environmentally significant behavior. Journal of Social Issues 56, 407-424. doi: 10.1111/0022-4537.00175

Stoll-Kleemann, S., O'Riordan, T., and Jaeger, C. C. (2001). The psychology of denial concerning climate mitigation measures: evidence from Swiss focus groups. Glob. Environ. Change 11, 107-117. doi: 10.1016/S0959-3780(00)00061-3

Stoll-Kleemann, S., and Schmidt, U. J. (2017). Reducing meat consumption to counter biodiversity loss and food insecurity: a review of influence factors. Reg. Environ. Change 17, 1261-1277. doi: 10.1007/s10113-016-1057-5

Swearingen, T. C. (1990). Moral development and environmental ethics. Dissert. Abs. Int. 50 (12-B, Part 1), 5905.

Thørgersen, J. (2004). A cognitive dissonance interpretation of consistencies and inconsistencies in environmentally responsible behavior. Journal of Environmental Psychology 24, 93-103. doi: 10.1016/S0272-4944(03) 00039-2
UNCLOS (1982). 1833 U.N.T.S. 3, 397; 21 I.L.M. 1261. Available online at: https:// www.refworld.org/docid/3dd8fd1b4.html (accessed March 01, 2019).

UNFCCC (2015). Adoption of the Paris Agreement. New York, NY: United Nations.

United Nations (2015). Transforming our World: The 2030 Agenda for Sustainable Development. New York, NY: United Nations.

Verplanken, B., and Roy, D. (2016). Empowering interventions to promote sustainable lifestyles: testing the habit discontinuity hypothesis in a field experiment. J. Environ. Psychol. 45, 127-134. doi: 10.1016/j.jenvp.2015.11.008

Vincent, A.C.J. (2011). Saving the shallows: focusing marine conservation where people might care. Aquat. Conserv. Mar. Freshw. Ecosyst. 21, 495-499. doi: $10.1002 /$ aqc. 1226

WBGU (2013). World in Transition. Governing the Marine Heritage. Flagship Report. German Advisory Council on Global Change, Berlin.

Whitley, S., van der Burg, L., Worrall, L., and Patel, S. (2017). Cutting Europe's Lifelines to Coal. Available online at: https://www.odi.org/sites/odi.org.uk/files/ resource-documents/11494.pdf (accessed December 17, 2018).

Whitmarsh, L., and O'Neill, S. (2011). “Introduction: opportunities for and barriers to engaging individuals with climate change," in Engaging the public with climate change, eds L. Whitmarsh, S. O'Neill, I. Lorenzoni (London: Earthscan), 1-14.

Wolff, R. (2018). Schweden meiden Flüge. Auf Schiene verreisen - oder gar nicht. taz. Retrieved from: https://taz.de/! 5549744 ? fbclid=IwAR0PcQVm7AgMp39mb7LBlvgWHVHPP_ YIJZxBx7Jsvu2TgvtBN4AT6ncqnJE (accessed December 17, 2018).

Wright, A. J., Veríssimo, D., Pilfold, K., Parsons, E. C. M., Ventre, K., Cousins, J., et al. (2015). Competitive outreach in the 21st century: why we need conservation marketing. Ocn. Coast. Manag. 115, 41-48. doi: 10.1016/j.ocecoaman.2015.06.029

Wynes, S., and Kimberly, A. N. (2017). The climate mitigation gap: education and government recommendations miss the most effective individual actions. Environ. Res. Lett. 12, 1-9. doi: 10.1088/1748-9326/aa7541

Conflict of Interest Statement: The author declares that the research was conducted in the absence of any commercial or financial relationships that could be construed as a potential conflict of interest.

Copyright (c) 2019 Stoll-Kleemann. This is an open-access article distributed under the terms of the Creative Commons Attribution License (CC BY). The use, distribution or reproduction in other forums is permitted, provided the original author(s) and the copyright owner(s) are credited and that the original publication in this journal is cited, in accordance with accepted academic practice. No use, distribution or reproduction is permitted which does not comply with these terms. 